\title{
PESANTREN RIYADLUL AWAMIL Kabupaten Serang-Banten
}

\author{
Oleh Euis Thresnawaty S. \\ Balai Pelestarian Sejarah dan Nilai Tradisional Bandung \\ Jln. Cinambo No. 136 Ujungberung Bandung \\ Email: euisthresnawaty@yahoo.com
}

Naskah diterima: 22 Maret 2010

Naskah disetujui: 27 Mei 2010

\begin{abstract}
Abstrak
Tantangan dunia pesantren semakin besar dan berat di masa kini dan masa mendatang. Paradigma "mempertahankan warisan lama yang masih relevan dan mengambil hal terbaru yang lebih baik", benar-benar penting untuk direnungkan kembali. Permasalahannya adalah karena dunia pesantren tidak hanya mempertahankan tradisi lama saja, tradisi lama itu tidak harus relevan untuk masa kini. Tidak bisa disangkal bahwa modernitas telah menawarkan banyak hal untuk direnungkan, terutama oleh kalangan pesantren. Karena hal tersebut maka dilakukan penelitian mengenai Sejarah Pesantren Riyadlul Awamil dengan tujuan untuk mengungkap latar belakang sejarah serta perkembangannya. Adapun metode yang digunakan adalah metode sejarah. Pada kenyataannya tidak semua pesantren melakukan perubahan. Bahkan sebagian besar tetap bartahan dengan sistem salafiyah atau tradisional. Salah satunya adalah Pesantren Riyadlul Awamil Kabupaten Serang yang telah berdiri sejak tahun 1908, dan tetap konsisten dengan tradisi salafiyahnya.
\end{abstract}

Kata kunci: Sejarah Pesantren, pendidikan.

\begin{abstract}
There are many challenges for pesantren. The challenges are getting bigger and heavier now as well as for the future. It would be important to reconsider the paradigm stated "preserving relevantly old heritage and taking a better new one". The problem is that pesantren does not merely preserving old traditions but they also have to take modernization into consideration. By conducting methods used in history, this research has main goal to reveal historical background dan development of Pesantren Riyadlul Awamil. The result is that making changes is not an easy way for pesantrens. Many pesantrens are still preserving their traditional system of education (salafiya), one of them is Pesantren Riyadlul Awamil in Serang which was founded in 1908.
\end{abstract}

Keywords: History of Pesantren, education.

\section{A. PENDAHULUAN}

Islamisasi atau proses penyebaran agama Islam di Indonesia, khususnya pada masyarakat Jawa telah berlangsung sejak beberapa abad yang silam. Wali Sanga, yaitu para mubaligh
Islam sangat giat menyebarkan agama Islam dengan cara yang damai. Para Wali Sanga ini menggunakan beberapa strategi dalam menyampaikan dakwahnya, antara lain dengan mendirikan pesantren. 
Salah satu tujuan didirikannya pesantren adalah sebagai pusat pendidikan Islam. Dalam pesantren itu, para wali melakukan kegiatan dakwah dan mengajar mengaji kepada para pengikutnya. Dengan demikian, lembaga pesantren merupakan pusat syiar Islam dan berfungsi untuk mencetak kader-kader penyebar Islam. Pesantrenpesantren terkenal yang didirikan oleh para wali, antara lain Pesantren Sunan Ampel di Ampel Denta dan Pesantren Sunan Giri di Gresik.

Secara sosio-historis, pondok pesantren merupakan lembaga pendidikan Islam tertua di Indonesia, jauh sebelum bangsa ini merdeka. Oleh karena itu sistem pendidikan pondok pesantren sejak lahir hingga kini masih tetap mengacu pada sistem pendidikan tradisional, atau disebut "Kurikulum Kitabi".

Pesantren pada dasarnya merupakan asrama pendidikan Islam tradisional, dimana para siswanya tinggal bersama dan belajar di bawah bimbingan seseorang atau lebih guru yang dikenal dengan sebutan Kiai atau Ajengan. Unsur-unsur pesantren yang kita kenal selama ini adalah: masjid, pondokan atau kobong, santri, pelajaran kitab-kitab Islam klasik yang sekarang dikenal dengan sebutan kitabkitab kuning, dan kiai. Menurut Dhofier, jika satu pengajian biasa, di langgar-langgar atau masjid-masjid berkembang sampai memiliki unsurunsur seperti yang disebut di atas, maka statusnya bisa berubah menjadi pesantren.

Pada tahun 1970-an terjadi perubahan yang cukup besar pada keberadaan pesantren sebagai sebuah sistem pendidikan. Pesantren sebagai sebuah bentuk sistem pendidikan tradisional mulai berubah. Perkembangan ini dapat dilihat dengan berdirinya pesantren-pesantren modern atau berubahnya pesantren tradisional menjadi pesantren modern. Sistem pendidikan pesantren modern lebih merujuk pada sistem pembelajaran dengan mengacu pada sistem pendidikan Barat yang menggunakan sistem klasikal, kurikulum, dan pembelajaran keduniawian.

Salah satu pesantren tradisional yang sampai saat ini tetap mempertahankan tradisi salafi adalah Pesantren Riyadlul Awamil. Pesantren yang telah berdiri sejak tahun 1908 ini memiliki rentang sejarah yang panjang dan memiliki peranan dalam perjuangan kemerdekaan Indonesia. Salah satu pemimpinnya bahkan turut berjuang pada masa penjajahan Belanda.

Tujuan penelitian ini adalah untuk mengungkap latar belakang sejarah Pesantren Riyadlul Awamil serta perkembangannya dengan ruang lingkup yang terbatas, yaitu Kabupaten Serang, Provinsi Banten dengan fokus utama pada sejarah Pesantren Riyadlul Awamil.

Penelitian ini dilakukan dengan menggunakan metode sejarah melalui empat tahapan, yaitu:

1. Heuristik atau proses pencarian dan pengumpulan sumber. Pada tahap heuristik ini digunakan teknik-teknik sebagai berikut:

a. Studi kepustakaan dilakukan di berbagai perpustakaan, baik di Bandung maupun di Serang.

b. Kerja lapangan, yaitu langsung ke tempat tujuan

c. Melakukan wawancara dengan tokoh-tokoh yang berperan atau mengetahui mengenai sejarah Pesantren Riyadlul Awamil. 
2. Kritik sumber untuk memperoleh kebenaran dan kejernihan data, baik kritik ekstern (tentang wujud sumber), kritik intern (tentang isi sumber), maupun melakukan perbandingan data yang berasal dari berbagai sumber.

3. Interpretasi, data mengalami proses pemberian makna dan penafsiran secara jelas dan lengkap.

4. Historiografi adalah proses terakhir dalam penulisan sejarah yang berupa proses merangkaikan fakta-fakta yang berhasil dihimpun dalam sebuah kisah sejarah.

\section{B. HASIL DAN BAHASAN}

\section{Penyebaran Islam di Jawa Barat}

Agama Islam masuk ke Jawa Barat dimulai di daerah pesisir utara. Cirebon dan Cimanuk adalah kota pelabuhan yang pertama dimasuki agama Islam melalui para saudagar muslim yang menetap di kota-kota pelabuhan tersebut. Setelah para saudagar muslim menetap, sebagian penduduk setempat berangsur-angsur memeluk agama Islam. Selanjutnya, salah satu kota pelabuhan yaitu Cirebon berkembang menjadi daerah kekuasaan Islam yang berdiri sendiri, sebagai hasil dari upaya Syarif Hidayatullah atau Sunan Gunung Jati yang didukung oleh Kesultanan Demak. Perkembangan selanjutnya tahun 1479, Cirebon berhasil melepaskan diri dari ikatannya dengan Kerajaan Sunda. Cirebon sebagai pusat kekuasaan dan syiar Islam berusaha keras melakukan Syiar Islam ke daerah sekeliling Cirebon, bahkan ke seluruh Jawa Barat.
Melihat perkembangan agama Islam di bawah Komando Cirebon dan Demak yang terus melebarkan pengaruhnya ke wilayah Barat, tentu menimbulkan kekhawatiran bagi kedudukan Kerajaan Sunda. Untuk mengantisipasi pengaruh Islam terhadap wilayah kekuasaannya, Kerajaan Sunda menjalin kerjasama dengan bangsa Portugis yang telah berkuasa di Malaka sejak tahun 1511. Ajakan kerjasama dari Kerajaan Sunda tersebut tentu saja disambut gembira oleh Portugis yang memang sudah berniat untuk mengembangkan pengaruhnya ke Kerajaan Sunda.

Adanya perjanjian persahabatan antara Kerajaan Sunda dan Portugis membuat Demak dan Cirebon menjadi gusar. Demak segera menempatkan pengaruhnya di pesisir Utara Jawa Barat, dengan maksud untuk memutuskan hubungan Kerajaan Sunda dengan Portugis di Malaka. Oleh karena itu, Demak berusaha merebut daerah-daerah Kerajaan Sunda yang terdapat di Pesisir Utara, seperti Banten dan Kalapa. Usaha ini dilakukan dengan mengirim pasukan yang dipimpin oleh Fatahillah.

Pasukan Demak yang dipimpin oleh Fatahillah terlebih dahulu singgah di Cirebon. Sementara itu Demak dan Cirebon mempunyai hubungan yang kuat dalam sebuah ikatan persahabatan yang dinamakan "Keluarga Besar Demak - Cirebon". Cirebon merasa mempunyai kepentingan yang sama dengan Demak, maka pasukan Cirebon ikut bergabung. Pasukan Demak Cirebon ini dipimpin langsung oleh Fatahillah dan Sunan Gunung Jati. Ekspedisi militer ini berhasil menguasai Banten pada tahun 1526. 
Ketika ekspedisi militer ini datang, di Banten telah ada kelompok masyarakat muslim yang ikut mendukung dan membantu pasukan Cirebon - Demak. Untuk sementara waktu Banten diperintah oleh Sunan Gunung Jati, yang kemudian menikah dengan Putri Kawunganten, putri penguasa Banten.

Pasukan Fatahillah berhasil merebut Sunda Kalapa pada tahun 1527 dan pada tahun yang sama berhasil menghalau dan mengusir pasukan Portugis yang datang ke Sunda Kalapa. Sejak terusirnya bangsa Portugis dari Sunda Kalapa, namanya kemudian diubah menjadi Jayakarta yang berarti kemenangan yang sempurna, dan Fatahillah ditetapkan sebagai Adipati Jayakarta dengan tetap berada di bawah kekuasaan Banten (Soekmono dalam Wiryono H, 2004:9).

Dengan penguasaan Sunda Kalapa tahun 1527, maka seluruh pesisir Utara Jawa Barat telah berhasil menjadi wilayah kekuasaan Islam. Cirebon dan Banten berkembang menjadi pusat penyebaran Islam, sehingga penyebaran Islam ke pedalaman Jawa Barat atau daerah Kerajaan Sunda dilakukan melalui dua front, yaitu Front Barat (Banten) dan Front Timur (Cirebon). Dengan dikuasainya dua wilayah tersebut, Kerajaan Sunda semakin terjepit, bahkan akhirnya hancur oleh serangan Banten di bawah pimpinan Maulana Yusuf pada tahun 1579.

\section{Islam Masuk ke Serang Banten}

Banten merupakan salah satu kota di Indonesia yang menyimpan catatan sejarah cukup panjang. Banten merupakan salah satu pusat penyebaran Islam yang berpengaruh besar dalam pengislaman di daerah Jawa Barat,
Jakarta (Sunda Kelapa), Lampung, Sumatera Selatan, dan beberapa daerah lain di sekelilingnya.

Daerah Serang atau Banten pada masa PraIslam dikenal sebagai sebuah pelabuhan perniagaan yang berada di bawah kekuasaan Kerajaan Hindu, Kerajaan Sunda yang berpusat di "Dayo" Pakuan, Bogor sekarang. Menurut kesaksian Tome Pires pada tahun 1513, Kerajaan Sunda memiliki kota pelabuhan di pesisir Utara Jawa Barat, seperti Banten, Kalapa, dan Cirebon. Ketiga kota tersebut mengalami kemajuan dan berkembang pada zaman Islam, sehingga dapat sejajar dengan kota pelabuhan internasional di Asia.

Kedudukan pelabuhan Banten menjadi sangat penting sebagai tempat persinggahan orang-orang Islam, setelah pada tanggal 5 Agustus 1511 Portugis berhasil merebut Malaka dari kekuasaan Sultan Malaka Makhmudsyah. Demikian juga dengan Samudra Pasai pada tahun 1521 dan Maluku. Portugis menaklukkan kerajaan/kesultanan tersebut dengan menggunakan cara yang licik, semuanya mereka lakukan demi kekuasaan, kekayaan dan tugas sucinya dalam menghancurkan umat Islam. Dengan menguasai Malaka, mereka mengharapkan dapat memonopoli semua perdagangan rempah-rempah dari Nusantara.

Terjadinya perubahan jalur perdagangan ini membawa pengaruh besar bagi perkembangan pelabuhan Banten yang terletak dekat Selat Sunda. Pelabuhan Banten kemudian berubah menjadi pelabuhan internasional yang ramai dan banyak disinggahi para pedagang Arab, Cina, maupun Peureulak. Selain melakukan transaksi 
perdagangan, para pedagang Islam dari daerah tersebut, juga berusaha menyebarkan agama Islam. Meskipun belum didapat data arkeologis yang menunjang, kegiatan penyebaran Islam di Banten diperkirakan sudah dimulai sejak abad VII atau VIII Masehi. Hal ini dapat dipastikan ketika Sunan Ampel Denta (salah seorang wali dari kelompok Wali Songo) datang ke Banten, ternyata telah banyak penduduk yang beragama Islam, walaupun penguasa setempat masih beragama Hindu. Demikian pula di Pecinan, kompleks orang-orang pedagang Cina, telah berdiri sebuah mesjid yang kemudian diperbaiki oleh Syarif Hidayatullah (Michrob, 1993: 9).

Menurut perkiraan pada abad ke7 Banten sudah menjadi pelabuhan yang banyak dikunjungi para saudagar dari luar, karena menurut dugaan, Banten yang berada di jalur perdagangan internasional telah memiliki hubungan dengan dunia luar sejak awal abad Masehi. Ketika Islam dibawa oleh para saudagar Arab ke Timur, diduga Banten telah menjadi sasaran dakwah Islam. Apabila mengacu pada berita Tome Pires, bahwa pada tahun 1512 - 1515 di daerah Cimanuk, kota pelabuhan, dan batas Kerajaan Sunda dengan Cirebon, banyak dijumpai orang Islam. Ini berarti bahwa pada akhir abad ke-15 Masehi di wilayah Kerajaan Sunda Hindu sudah ada masyarakat yang beragama Islam.

Islamisasi terus dilanjutkan oleh Hasanuddin dengan berdakwah dari satu daerah ke daerah lainnya. Tahun 1525 Hasanuddin berhasil mengalahkan Prabu Pucuk Umum di Wahanten
Girang (Banten Girang). Selanjutnya atas petunjuk Sunan Gunung Jati, Hasanuddin memindahkan pusat pemerintahan Banten, yang semula berada di pedalaman Banten Girang, 3 $\mathrm{km}$ dari kota Serang ke dekat pelabuhan Banten. Peristiwa ini terjadi pada tanggal 1 Muharam tahun 933 Hijriah yang bertepatan dengan tanggal 8 Oktober 1526 (Michrob, 1993:68).

Sultan Hasanudin adalah Sultan Banten pertama. Pada masa kekuasaannya, ia lebih menekankan bidang keagamaan sebab ayahnya memang telah mempersiapkannya untuk menyebarkan agama Islam. Selain melakukan syiar Islam, Sultan Hasanuddin juga melakukan perluasan daerah dan perdagangan, Pelabuhan Banten dikembangkan menjadi pelabuhan transit atau persinggahan saudagar asing seperti dari India, China, Persia, dan Gujarat. Oleh karena itu, Banten berkembang menjadi Pusat Penyebaran agama Islam di Jawa Barat.

\section{Pengertian Pesantren}

Pesantren di Jawa dan Madura dikenal dengan nama pondok atau pondok pesantren. Istilah pondok sebenarnya berasal dari istilah funduk dari bahasa Arab yang artinya hotel atau asrama (Yacub:1993:65). Pesantren adalah lembaga pendidikan agama Islam, yang di dalamnya secara umum memiliki elemen-elemen, yaitu pondok (asrama), masjid, santri, pengajaran kitab-kitab Islam klasik, dan kiai. Keberadaan pesantren umumnya lebih banyak berada di daerah pedesaan. Pendidikan pesantren ini sangat erat hubungannya dengan kondisi sosial budaya masyarakat setempat, sehingga pesantren menjadi bagian integral dari masyarakat itu 
sendiri, masih banyak masyarakat yang lebih percaya terhadap pendidikan pesantren daripada pendidikan umum.

Secara etimologi, kata pesantren berasal dari bahasa Tamil yang berarti "guru ngaji”. Ada pula sumber yang menyebutkan bahwa kata pesantren berasal dari bahasa India yaitu Shastri dari kata Shastra yang berarti "bukubuku suci, buku-buku agama" atau buku-buku tentang ilmu pengetahuan". Dengan demikian, pesantren dapat diartikan sebuah tempat untuk belajar atau mempelajari buku-buku agama dan ilmu pengetahuan (Tim Sejarah, 2000; 106).

Menurut Dhofier (1990:18), pesantren berasal dari kata Santri, yang diberi awalan pe- dan akhiran -an. Pesantren artinya tempat tinggal para santri. Sementara itu, H.M. Yacub (1993:65) berpendapat bahwa pesantren adalah lembaga pendidikan Islam yang umumnya dilakukan dengan cara nonklasik, pengajarnya seseorang yang menguasai ilmu agama Islam melalui kitab-kitab klasik. Intinya pesantren adalah lembaga pendidikan yang menggunakan metode tradisional bandongan, sorogan, atau pun wetonan. Para Santri atau pelajar disediakan pondokan atau asrama di dalam lingkungan pesantren. Pengajarnya adalah kiai dan mesjid sebagai pusat pendidikan secara substansial.

Terjadinya perubahan dan perkembangan pada lembaga pendidikan pesantren, adalah awal tahun 1970an ketika sistem pendidikan pondok pesantren mengadopsi sistem sekolah atau madrasah, dikenal dengan sebutan pondok pesantren modern. Dengan adanya perkembangan dan perubahan bentuk pondok pesantren, maka
Menteri Agama Republik Indonesia mengeluarkan Peraturan Menteri Nomor 3 tahun 1979 tentang pesantren. Peraturan tersebut mengklasifikasikan pondok pesantren sebagai berikut :

1. Pondok Pesantren Tipe A, yaitu para santri belajar dan bertempat tinggal di asrama lingkungan pondok pesantren dengan pengajaran yang berlangsung secara tradisional (Sistem Wetonan atau Sorogan).

2. Pondok Pesantren Tipe B, yaitu yang menyelenggarakan pengajaran secara klasik, dan pengajaran oleh kiai bersifat aplikasi, diberikan pada waktu-waktu tertentu. Santri tinggal di asrama lingkungan pondok pesantren.

3. Pondok Pesantren Tipe C, yaitu pondok pesantren hanya merupakan asrama, sedangkan para santrinya belajar di luar (Madrasah atau Sekolah Umum), kiai hanya mengawasi dan sebagai pembina para santri tersebut.

4. Pondok Pesantren Tipe D, yaitu yang menyelenggarakan sistem pondok pesantren dan sekaligus sistem sekolah atau madrasah (Noor, Mahpuddin, 2006: 44).

Dari sekian banyak tipe pondok pesantren dalam menyelenggarakan pendidikan dan pengajaran bagi santrinya, secara garis besar dapat dikelompokkan ke dalam dua bentuk pondok pesantren:

Pondok Pesantren Salafiah, yaitu yang menyelenggarakan pengajaran AlQur'an dan ilmu-ilmu agama Islam, serta kegiatan pendidikan dan pengajarannya sebagaimana yang berlangsung sejak awal pertumbuhannya.

Pondok Pesantren Khalafiah, yaitu pondok pesantren yang selain 
menyelenggarakan kegiatan pesantrenan, juga menyelenggarakan kegiatan pendidikan formal sekolah dan madrasah.

Pesantren Salafiah adalah sistem pesantren yang tetap mempertahankan sistem atau materi pengajaran yang sumbernya dari kitab-kitab klasik Islam atau dikenal dengan sebutan Kitab Kuning. Keberadaan pondok pesantren dengan tipe pondok pesantren Salafiah terbukti jumlahnya paling banyak, bahkan beberapa pondok pesantren sama sekali menolak program wajib belajar dari Dinas Pendidikan Nasional. Mereka tidak mau mengakomodasikan sistem pendidikan sekolah atau madrasah ke dalam sistem pendidikan pesantren yang telah lama ditekuni. Dalam hal ini Pesantren Riyadlul Awamil termasuk dalam kelompok pesantren Salafiah yang tetap bertahan dengan sistem tradisionalnya.

\section{Sejarah Pesantren Riyadlul Awamil}

Sejarah pesantren hampir tidak mungkin dilepaskan dari sejarah bangsa Indonesia. Hal ini berawal sejak penjajah Belanda menyingkirkan otoritas para ulama dari pentas sosial politik nasional atas saran Snock Hurgronye. Inti dari saran tersebut adalah bahwa umat Islam akan terusik dan akan melakukan gerakan progresif yang mungkin tidak bisa dibendung oleh Pemerintah Belanda, ketika mereka diusik aspek ibadahnya. Oleh karena itu, dia menyarankan agar Pemerintah Belanda membiarkan umat Islam melakukan ibadahnya. Dengan demikian akan muncul sebuah asumsi bahwa Belanda menghargai agama pribumi. Sebaliknya, dia menyarankan agar umat Islam tidak diberi kesempatan untuk berkiprah dalam dunia sosial politik, karena akan membuat Pemerintah Belanda menghadapi gerakan politik mereka yang kuat. Berdasarkan hal diatas, Pemerintah Belanda kemudian membatasi ruang gerak umat Islam, terutama para tokoh agamanya. Aktivitas umat Islam terbatas pada ibadah. Untuk ketenangan beribadah tersebut, mereka melakukan perpindahan ke tempat-tempat terpencil yang terlepas dari gangguan penjajah Belanda. Di daerah-daerah itu para tokoh agama mendirikan kumpulankumpulan dan lembaga-lembaga tradisional, di antaranya adalah pesantren untuk mengajarkan umat Islam tentang ajaran Islam.

Berdirinya sebuah pesantren tidak dapat dipisahkan dari keadaan sosial budaya masyarakat sekitarnya. Tidak jarang tempat asal mula pesantren berada di perkampungan kecil atau kampung yang penduduknya belum beragama atau belum menjalankan syariat agama Islam. Sekalipun tidak ada catatan tertulis mengenai keberadaan awal berdirinya sebuah pesantren. Pada zaman dulu biasanya pesantren didirikan di daerah pedesaan, yang terkadang jauh dari keramaian masyarakat, misalnya di perbukitan.

Latar belakang berdirinya pesantren di Indonesia umumnya memiliki kesamaan, yaitu dimulai dengan usaha seseorang atau beberapa orang secara pribadi atau kolektif, yang mempunyai keinginan mengajarkan ilmu pengetahuan agama kepada masyarakat luas, mereka membuka kesempatan pengajian secara sederhana kepada penduduk setempat. Biasanya diawali dengan pengajian yang dilaksanakan dengan cara berlatih membaca Alquran di 
mushola atau masjid yang sederhana. Beberapa waktu kemudian tumbuh kesadaran masyarakat setempat terhadap pengetahuan agama dan kelebihan yang dimiliki oleh mereka yang mengajar. Pada akhirnya banyak masyarakat sekitar yang belajar agama. Mereka memanggil pengajarnya dengan sebutan "kiai", di Jawa Barat di sebut "Ajengan". Adapun mereka yang menuntut ilmu agama di tempat itu disebut santri ( Dhofier; 1990; 51 - 60).

Sejak awal, Banten telah di kenal sebagai tempat menimba ilmu dan memberikan kontribusi bagi perkembangan ajaran Islam. Banten telah melahirkan beberapa putra daerahnya sebagai ulama besar yang mendunia, sebagai contoh adalah imam besar Syekh Nawawi Al-Bantani (1230 Hijriah/1815 Masehi). Ulama besar dengan gelar "Sayyid Ulama Al-Hijaz" atau "pemimpin para ulama Hijaz" ini telah banyak menulis dan hasil tulisannya telah beredar terutama di negara-negara yang menganut faham Syafi'yyah. Tentu saja hal tersebut telah turut membangkitkan inspirasi para ulama untuk mendirikan pesantren di wilayahnya dalam melakukan Syiar Islam.

Salah satu ulama yang terinspirasi adalah pendiri Pesantren Riyadlul Awamil yang lebih di kenal dengan nama Pesantren Cangkudu, yaitu Abuya Muhammad Sidiq. Pondok Pesantren Cangkudu terletak di Kampung Cangkudu, Desa Sukamanah, Kecamatan Baros, Kabupaten Serang. Jumlah penduduknya pada tahun 2001 adalah 44.023 jiwa, terdiri atas 22.837 pria dan 21.186 wanita dengan kepadatan penduduk per kilometer persegi adalah 1015. Di wilayah Kampung Cangkudu saat ini terdapat
21 pesantren, 57 mesjid, 22 mushola, dan 113 langgar. Untuk sarana pendidikan sendiri tersedia 24 Sekolah Dasar (SD), 3 Sekolah Lanjutan Pertama, 1 Sekolah Lanjutan Atas, 24 Madrasah Diniyah, 4 Ibtidaiyah, 3 Tsanawiyah, dan 2 Aliyah.

Pesantren ini didirikan berkat usaha sendiri dari Abuya K.H. Muhammad Sidiq, salah satu santri dari tokoh pesantren, ulama besar Syekh Nawawi al-Bantani Al-Jawi pada tahun 1908. Pesantren ini didirikan seiring dengan kepergian kembali Syekh Nawawi Al-Bantani ke Mekah. Syekh Nawawi al-Bantani yang telah menjadi panutan banyak ulama adalah ulama terkenal yang dilahirkan pada tahun 1230 Hijriah (1815 Masehi) di Desa Tanara, Banten. Dari keturunan ayahnya, Syekh Nawawi merupakan salah satu keturunan Maulana Hasanudin, putra Sunan Gunung Jati.

Bangunan Pondok Pesantren ini dibangun di atas tanah milik sendiri seluas 10 hektar. Tidak heran apabila di kemudian hari estafet pengelolaan Pesantren Cangkudu tidak jatuh ke tangan orang lain, tapi diturunkan pada garis keturunan atau kerabat dekatnya. Pewarisan kepemimpinan pesantren yang bersifat geneologis ini merupakan sesuatu yang wajar dalam dunia pesantren di Indonesia.

Pada awal berdirinya Pesantren Cangkudu hanya memiliki sekitar 30 orang santri, berasal dari masyarakat sekitar pesantren untuk melakukan pengajian. Digelarnya pengajian Alquran semula khusus untuk anakanak yang diadakan setiap bada Magrib, kecuali malam Jumat karena pada malam Jumat pengajian diadakan untuk umum, berlaku untuk orang dewasa dan anak-anak. Pengajian yang 
semula hanya mengajarkan ilmu Alquran, kemudian secara bertahap ditambah dengan pelajaran agama yang lainnya, seperti ilmu fiqih, aqidah, dan menulis huruf Arab. Hal ini dimaksudkan agar anak-anak tidak hanya pandai baca Alquran, tetapi mereka diharapkan mampu menguasai pengetahuan tentang ilmu agama.

Untuk menyelenggarakan pendidikan agama di pesantren pada saat itu, bukanlah suatu hal yang mudah. Selain pengawasan ketat yang dilakukan oleh penjajah Belanda yang selalu melakukan politik adu dombanya, tingkat sosial politik dan ekonomi masyarakat juga kurang mendukung. Belum lagi adanya benturan dengan kepercayaan masyarakat lokal yang masih jauh dari tradisi nilai-nilai keIslaman. Selain itu Pesantren Cangkudu ini kerap kali dijadikan tempat persembunyian para pejuang yang dikejar oleh Kolonial Belanda.

Kegiatan pengajian di Pesantren Cangkudu ini sama sekali tidak dipungut bayaran. Hal ini disebabkan kehidupan ekonomi kiai atau pemimpin pesantren relatif lebih dari cukup. Tanah yang dimiliki Abuya K.H. Muhammad Sidiq cukup luas. Para santri yang menimba ilmu dengan rela menggarapnya, ini dilakukan oleh santri yang berasal dari daerah yang jauh atau santri mukim. Adapun santri kalong atau santri yang berasal dari daerah sekitar pesantren sering memberikan hadiah-hadiah, baik berupa hasil bumi maupun barang-barang yang dianggap pantas untuk kiai sebagai rasa hormat.

Abuya K.H. Muhammad Sidiq mempunyai 10 anak dari 4 istri, yaitu Hajah Supiah, Hajah Sarwah, Hajah
Sanah, dan Hajah Saki. Kesepuluh putra-putrinya adalah:

1. H. Juhadi

2. Hj. Wariah

3. Hj. Rumsah

4. K.H. Ali

5. H. Adung

6. Hj. Aisyah

7. H. Ahad

8. H. Muhammad

9. H. Juned

10. Hj. Sabsah

Kini, dari sepuluh putra K.H. Muhammad Sidiq hanya ibu Hj. Aisyah yang masih ada. Meskipun telah berusia lanjut tetapi masih nampak sehat dengan daya ingat yang masih tajam. Ia masih mampu menguraikan silsilah keluarga besar Abuya K.H. Muhammad Sidiq, pendiri Pesantren Riyadlul Awamil Cangkudu.

Tahun 1946 kepemimpinan pesantren diserahkan kepada putranya, K.H Ali. Akan tetapi kepemimpinan K.H. Ali tidak berlangsung lama karena ia lebih memilih menjadi pejuang aktif melawan penjajah Belanda. Tahun 1946/1947 adalah tahun terakhir perjuangannya karena ia dipanggil Allah SWT, dan dimakamkan di "Makam Seribu" Serpong Tangerang.

Setelah K.H. Ali meninggal pada tahun 1947 kepemimpinan pesantren dilanjutkan oleh salah seorang menantu Abuya K.H. Muhammad Sidiq, yaitu Abuya K.H. Abdul Salam, suami dari Hj Aisyah, putrinya. Pada tahun 1947 pula, duka mendalam dirasakan segenap warga Pesantren Riyadlul Awamil Cangkudu. Tepatnya tanggal 30 Agustus 1947 atau 15 Syawal 1366, Abuya Muhammad Sidiq meninggal dunia. Meskipun Abuya K.H. Muhammad Sidiq sebagai pendiri 
pesantren telah wafat, ternyata tidak menyurutkan santri-santri yang ingin belajar di pesantren ini. Pada tahun 1947-1970 jumlah santri yang menuntut ilmu di pesantren ini mencapai 1.000 orang, berasal dari berbagai daerah di Banten, Jawa Barat, Jawa Tengah, Jawa Timur, Lampung, Medan, dan lain-lain.

Pada tahun 1972 K.H. Abdul Salam menyerahkan kepemimpinan pesantren kepada salah satu menantunya, yaitu K.H. Abad Badrudin, suami dari $\mathrm{Hj}$. Enjoh, putrinya. K.H. Abad Badrudin dikenal sebagai kiai yang ulet dan bijaksana. Ia banyak menyerap ilmu dari berbagai pesantren di antaranya Pesantren Cireundeu Rangkasbitung, Pesantren Bojong Menteng Rangkas-bitung, Pesantren Kadu Kaweng Pandeglang, Pesantren Cibeureum Sukabumi, Pesantren Panguragan Cirebon, Pesantren Sadang Garut, dan Pesantren Gentur Cianjur. Kemudian ia memberi nama Pesantren Cangkudu menjadi "Riyadlul Awamil". Riyadlul artinya taman, ladang, atau kebun, sedangkan awamil diambil dari salah satu kitab dasar ilmu nahwu, yaitu 'amil. Tahun 1979 K.H. Abad Badrudin memindahkan kegiatan pendidikan santri dari masjid jami Cangkudu ke lokasi pondokan sekarang. Jumlah santri pada tahun 1992/1993 mencapai 700 orang. Selama masa kepemimpinannya, Pesantren Riyadlul Awamil Cangkudu banyak mengalami perkembangan. Akan tetapi pada tahun 1993 kiai yang dikenal bijaksana ini meninggal dunia dengan meninggalkan seorang istri, dan 9 anak serta para santrinya (Bhaedhawy, dkk:TT:38).

Kepemimpinan pesantren selanjutnya diserahkan kepada putra sulungnya, yaitu Sonhaji. Meskipun usianya masih belia, 17 tahun, tetapi ia telah dipersiapkan dengan dibekali ilmu pengetahuan yang diterima langsung dari ayahnya. Selain itu, Sonhaji pun selama 40 hari menuntut ilmu sebagai santri di Kadu Kaweng Pandeglang. Meskipun usianya masih muda, tetapi ia berhasil mengembangkan kembali Pesantren Riyadlul Awamil bersama 5 pengurus pesantren lainnya, yaitu: K.H. Ahyani, K.H. Nahrowi, K.H. Salim, K.H. Rifai, dan K.H. Sanhudi. Tahun 2002 ia mempersunting $\mathrm{Hj}$. Yeyen yang berasal dari Ciomas dan dikaruniai 2 putra dan putri.

Pesantren dengan fasilitas yang tetap mempertahankan tradisi salafi ini selain ditandai oleh sistem pengajaran, administrasi yang sangat sederhana, juga telah memiliki program unggulan di luar pengajaran ilmu agama Islam (pengajian Kitab Kuning). Program unggulan tersebut adalah Sekolah Menengah Kejuruan (SMK Pesantren) dengan program Teknologi Informatika (TI) yang mengarah pada penguasaan komputer (multimedia). Saat ini sudah ribuan alumni yang telah berhasil dan mendirikan pondok pesantren di berbagai wilayah Indonesia.

\section{Unsur-unsur Pesantren}

Setiap pesantren mempunyai tiga unsur dasar atau pokok, yaitu pengasuh, santri, dan sarana fisik. Pengasuh terdiri atas kiai dan guru. Guru laki-laki disebut ustaz, sedangkan guru perempuan disebut ustazah. Santri adalah murid yang sedang menuntut ilmu agama Islam di pesantren. Adapun yang disebut sarana fisik, yaitu masjid, pondok, madrasah tempat belajar, dan kitab-kitab Islam klasik. Menurut 
Zamakhsyari Dhofier sebuah pesantren mempunyai lima elemen dasar dari tradisi pesantren, yaitu pondok, masjid, santri, pengajaran kitab-kitab Islam, dan kiai. Artinya, jika suatu lembaga pengajian yang telah berkembang hingga memiliki lima elemen tadi, maka statusnya akan berubah menjadi sebuah pesantren.

\section{a. Santri}

Keberadaan santri di Pesantren Cangkudu dari tahun ke tahun tidak sama. Sejarah Pesantren Cangkudu menunjukkan bahwa pada awal pendirian oleh Abuya K.H. Muhammad Sidiq tahun 1908 hanya memiliki santri sekitar 30 orang. Mereka terdiri atas warga sekitar, merekalah yang pertama kali menempati kobong asrama santri di Pesantren Cangkudu. Pengajian di Pesantren Cangkudu selain diikuti oleh santri mukim, juga diikuti oleh santri kalong yang berasal dari pemuda dan masyarakat yang berada di sekitar pesantren.

Jumlah santri Pesantren Riyadlul Awamil Cangkudu mengalami pasang surut, seiring dengan perkembangan zaman. Masa-masa memprihatinkan terjadi pada masa penjajahan Jepang dan masa Revolusi Fisik karena pada masa itu banyak santri mukim yang kembali ke daerah asalnya masingmasing. Banyak di antaranya ikut terlibat langsung dalam mempertahankan dan menegakkan Negara Republik Indonesia dengan menjadi anggota laskar pejuang di daerahnya masingmasing.

Sampai tahun 1945 jumlah santri masih terbilang cukup banyak, yaitu sekitar 600 orang. Akan tetapi antara tahun 1947 - 1970 keberadaan santri semakin meningkat menjadi 1.000 orang santri dari berbagai daerah Banten, Jawa Barat, Jawa Tengah, Jawa Timur, Lampung, Medan, dan lainnya, meskipun Abuya K.H. Muhammad Sidiq telah meninggal. Tahun 1992/1993 jumlah santri kembali menurun menjadi 700 orang. Sekarang jumlah santri yang mondok di pesantren ini mencapai 500 orang, belum termasuk santri kalong yang datang menjelang senja dan pulang setelah subuh. Santri tersebut dapat dibedakan menjadi dua kelompok, yaitu santri mukim dan santri kalong. Santri mukim yaitu santri yang menetap, berasal dari daerah luar pesantren. Komunitas santri mukim merupakan komunitas santri yang paling serius dalam mempelajari pelajaran-pelajaran di pesantren. Santri mukim ditempatkan di asrama pesantren, dengan kamar-kamar yang berderet rapih. Biasanya mereka berkelompok sesuai dengan daerah asal mereka, misalnya pondok Laskar Betawi, Banten, Bogor, Lampung, dan sebagainya. Tersedia pula di sana 3 tempat pemandian besar dan dapur umum yang bersih. Santri kalong, adalah kelompok santri yang berasal dari warga sekitar pesantren. Mereka tidak menetap, melainkan pulang pergi ke rumahnya atau didugdag menurut istilah bahasa Sunda.

Penerimaan santri dilakukan kapan saja, tidak terikat oleh waktu, atau dengan kata lain keluar masuk santri tidak diatur dengan peraturan baku. Santri yang masuk dan keluar sesuai dengan kehendak santri. Akan tetapi pada umumnya mereka tetap bertahan minimal 9 tahun belajar di pesantren ini. Selanjutnya mereka dipersilakan untuk meneruskan ke 
pesantren lainnya, misalnya ke Pesantren Kadu Kawung Pandeglang. Para santri pesantren ini tidak dikenakan pungutan apa pun, kecuali untuk listrik setiap bulannya. Setiap pondok berada di bawah tanggung jawab dan binaan seorang pengajar pesantren, umumnya masih anggota keluarga pesantren.

\section{b. Pondok}

Setiap pesantren biasanya mempunyai pondok, yaitu tempat tinggal santri selama belajar di pesantren. Sebuah pondok pesantren pada dasarnya adalah sebuah asrama pendidikan Islam tradisional. Para siswanya tinggal bersama dan belajar di bawah bimbingan seorang atau lebih guru yang dikenal dengan sebutan kiai. Kompleks Pesantren biasanya dikelilingi tembok agar keluar masuknya santri dapat diawasi sesuai dengan peraturan yang berlaku. Ketentuan seperti itu tidak akan ditemui di Pesantren Riyadlul Awamil Cangkudu, karena pesantren ini mempunyai sistem terbuka, tidak ada tembok atau pun pagar pembatas. Artinya tidak ada pemisah fisik antara pondok pesantren dengan kehidupan masyarakat di sekitarnya, semuanya berjalan apa adanya. Di dalam lingkungan areal pesantren terdapat bangunan induk yang terdiri atas rumah-rumah kiai dan keluarganya, tempat belajar, pondokpondok yang berjejer rapih dan masjid jami sebagai pusat segala kegiatan.

Rumah-rumah induk ditempati oleh keluarga keturunan Abuya K.H. Muhammad Sidiq, yaitu keluarga K.H. Ali, K.H. Abdul Salam, K.H. Abad Badrudin, K.H. Sonhaji, dan keluarga kerabat pesantren seperti K.H. Ahyani, K.H. Nahrowi, K.H. Udi, K.H. Salim dan yang lainnya. Semuanya tersebar di areal Pesantren Riyadlul Awamil Cangkudu, berbaur dengan pondokpondok para santri. Khususnya untuk pondok santri putri, letaknya terpisah dari pondok santri laki-laki. Untuk pondokan santri putri terletak di dalam areal rumah anggota keluarga pengurus pesantren, salah satunya terletak di areal belakang rumah ibu $\mathrm{Hj}$. Aisyah.

\section{c. Masjid}

Masjid pada hakikatnya mempunyai multifungsi sesuai dengan yang telah dicontohkan oleh Nabi Muhammad Saw. Masjid merupakan unsur atau elemen yang tidak dapat dipisahkan dengan pesantren dan dianggap sebagai tempat yang paling tepat untuk mendidik para santri. Di masjid para santri melakukan praktik salat lima waktu, khutbah dan salat Jumat, serta pengajaran kitab-kitab Islam klasik.

Masjid Jami di Pesantren Riyadlul Awamil Cangkudu cukup besar dan permanen. Terletak di bagian depan areal pesantren, berdampingan dengan rumah-rumah dan pondokpondok santri. Sepintas mirip rumah biasa, milik pengurus pesantren yang rata-rata cukup luas. Yang membedakannya karena masjid memiliki cungkup.

\section{d. Kiai}

Kiai adalah komponen yang paling esensial dari sebuah pesantren, bahkan seringkali merupakan pendirinya. Oleh karena itu pertumbuhan dan perkembangan pesantren seringkali sangat ditentukan oleh kemampuan pribadi dari figur seorang kiainya.

Pada awal berdirinya Pesantren Riyadlul Awamil Cangkudu dipimpin 
oleh Abuya K.H. Muhammad Sidiq, yang bertindak sebagai pendidik dan sekaligus sebagai pendiri dan pemilik pesantren. K.H. Muhammad Sidiq biasa dipanggil Abuya oleh masyarakat setempat. Dialah pendidik Pesantren Riyadlul Awamil Cangkudu. Dalam tradisi kepesantrenan, pendidik atau guru mengaji umumnya masih berasal dari lingkungan keluarga pendiri dan pemilik pesantren. Demikian juga para pendidik yang ada di Pesantren Riyadlul Awamil Cangkudu, sebagian besar adalah keluarga Abuya K.H. Muhammad Sidiq, pendiri Pesantren Riyadlul Awamil Cangkudu. Mereka adalah keturunan langsung (anak, cucu) atau menantu.

\section{e. Pengajaran Kitab-kitab Islam Klasik}

Kitab-kitab Islam klasik, terutama karangan-karangan ulama yang menganut paham Syafi'iyah merupakan bahan pengajaran formal yang diberikan di lingkungan pesantren. Paham Syafiiyah atau mazhab Imam Syafii mempunyai pengaruh yang besar di Indonesia, terlihat pada kitab-kitab fiqih yang banyak dipelajari di pesantren-pesantren. Para santri diwajibkan untuk mempelajari kitabkitab Islam. Tujuannya tentu saja untuk mendidik calon ulama dan Kiai. Para santri yang mempunyai cita-cita menjadi ulama harus bertahun-tahun di pesantren untuk menguasai berbagai cabang pengetahuan Islam.

Materi pelajaran yang diberikan kepada santri umumnya berkisar pada masalah keagamaan seperti tauhid, fiqih, dan lain-lain. Materi tersebut biasanya berkaitan dan bersumber dari kitab klasik atau kitab kuning. Kitab kuning sering pula disebut oleh kalangan pesantren sebagai kitab gundul, karena huruf yang dipakai tidak menggunakan sandangan fathah, dhammah, dan kasroh. Kitab ini pun sering disebut kitab kuno, karena berasal dari zaman yang telah lampau.

Adapun kitab yang dipelajari adalah 'Amil, al-Jurumiyah, Matan Bina, Yaqulu, Imriti dan al-Fiyah untuk Ilmu Nahwu Sharraf. Sarah Sittin, Riyadl al-Badi'ah, Taqrib, Fath alQarib dan Fath al-Mu'in untuk ilmu Fiqh. Untuk Tafsir yang diajarkan adalah Tafsir Munir dan Jalalain, sedangkan untuk Ilmu Tauhidnya adalah Tijan ad-Daruri (Baedhawy, dkk:TT,39).

\section{Sistem Pendidikan}

Setiap pesantren selalu mempunyai sistem tersendiri dalam mendidik anak didiknya. Pesantren Riyadlul Awamil Cangkudu yang didirikan tahun 1908, tidak terlepas dari pengaruh lingkungan, sehingga sistem pendidikan pun ikut sejalan dengan situasinya. Proses pembelajarannya masih menggunakan cara penyampaian yang umum dilakukan di pesantrenpesantren tradisional. Dalam hal ini Pesantren Riyadlul Awamil Cangkudu tetap memiliki elemen-elemen pokok yang menjadi ciri penyelenggaraan pendidikan pesantren tradisional, antara lain kiai, santri, pengajian kitab klasik atau kitab kuning, masjid, dan asrama atau pondok santri.

Pesantren Riyadlul Awamil Cangkudu adalah lembaga pendidikan yang tidak memiliki kurikulum baku yang formal, tentu saja tidak memiliki sistem evaluasi yang terencana. Berhasilnya seorang santri tidak dapat diukur dengan tanda bukti berupa Ijazah atau Surat Tanda Tamat Belajar, 
tetapi lebih ditentukan oleh penguasaan kitab dan di sahkan oleh kiai. Penggantian suatu kitab dengan kitab lainnya dapat dianggap sebagai tingkat keberhasilan seorang santri. Oleh karena itu, ukuran keberhasilan atau evaluasi di pondok Pesantren Riyadlul Awamil Cangkudu tidak dapat dilakukan secara khusus dan terjadwal sebagaimana jenjang pendidikan dan tingkatan kelas pada sekolah.

\section{PENUTUP}

Pesantren memiliki sejarah pertumbuhan dan perkembangan yang panjang, bahkan telah menjadi bagian yang integral dari sistem pendidikan nasional. Pesantren sekarang bukanlah lembaga tertutup dan terkesan 'terbelakang', tetapi sebuah lembaga pendidikan agama Islam yang cukup handal.

Pesantren Riyadlul Awamil Cangkudu didirikan oleh Abuya K.H. Muhammad Sidiq murid Syekh Nawawi al-Bantani pada tahun 1908 di Kampung Cangkudu, Desa Sukamanah, Kecamatan Baros, Kabupaten Serang, Propinsi Banten, dahulu masih ada dalam wilayah Provinsi Jawa Barat. Oleh karena pesantren ini terletak di Kampung Cangkudu, maka namanya lebih dikenal dengan nama Pesantren Cangkudu. Akan tetapi pada tahun 1972, ketika di bawah kepemimpinan K.H. Abad Badrudin pesantren ini dinamakan Pesantren Riyadlul Awamil. Pada kenyataannya orang tetap mengenalnya dengan nama Pesantren Riyadlul Awamil Cangkudu.

Pesantren yang didirikan atas biaya sendiri ini mengalami perkembangan yang pasang surut, terutama pada masa penjajahan Belanda. Salah satu pimpinannya, yaitu K.H. Ali cenderung lebih memilih berjuang di medan perang hingga gugur. Bahkan pesantren ini pun sering digunakan sebagai tempat persembunyian pejuang dari kejaran tentara Belanda. Dalam sistem pendidikannya, pesantren ini tetap mempertahankan tradisi Salafiyah dengan materi pelajaran khusus berstandar pada kitab-kitab klasik seperti umumnya pesantren-pesantren tradisional. Dalam segi administrasinya masih menggunakan cara-cara yang sangat sederhana. Misalnya, keluar masuk santri tidak diatur dengan peraturan baku, kapan saja seseorang ingin menjadi santri tinggal melakukan pendaftaran, bila ingin keluar pun tidak ada pelarangan. Setiap santri tidak dipungut bayaran kecuali untuk iuran listrik setiap bulan.

Sampai saat ini Pesantren Riyadlul Awamil masih konsisten dengan tradisi Salafiahnya dengan administrasi yang sangat sederhana. Di satu sisi tentu sangat menolong dan menguntungkan kalangan masyarakat menengah ke bawah karena dengan sistem ini masyarakat yang tidak mampu tidak terlalu terbebani dengan masalah dana. Tetapi di sisi lain dengan bebasnya keluar masuk santri akan memiliki dampak yang tidak baik. Misalnya, dengan bebasnya keluar masuk santri bukan tidak mungkin akan dimanfaatkan oleh orang-orang yang tidak bertanggung jawab yang akan membawa pengaruh buruk untuk para santri.

Selain itu, sebaiknya pesantren yang kini hanya menyelenggarakan pendidikan kitab kuning sudah saatnya peduli terhadap kajian ilmiahakademik, yang dapat dilakukan melalui penyediaan buku-buku umum 
sebagai pelengkap kepustakaan, kemudian diimbau agar santri mau membaca buku-buku tersebut sehingga pengetahuan mereka tentang pengetahuan umum bisa berkembang. Hal itu tentu sebagai upaya melihat realitas empirik, tanpa harus mengganggu jadwal pengajian kitab kuning. Pengurus pesantren tentu harus menentukan jadwal kapan membaca buku dan kapan mengaji dan mengkaji kitab.

\section{DAFTAR PUSTAKA}

Adeng. 2002.

Sejarah Pesantren Darul Salam Ciamis. Bandung: BKSNT.

A'la, Aled. 2006.

Pembaruan

Yogyakarta:

Pesantren
LKIS Pelangi

Aksara.

Asy’ari, Zubaidi H. 1996.

Moralitas Pendidikan Pesantren. Yogyakarta: LKPSM.

Baedhawy, Ruby dkk. Tt.

Profil Pesantren Salafi Banten.

Banten: Biro Humas Setda Prov.

Banten.

Depag RI. 2003.

Pola Pengembangan Pondok Pesantren. Jakarta: Binbaga Islam.

Dhofier, Zamakhsyari. 1990.

Tradisi Pesantren Studi tentang

Pandangan Hidup Kyai, Jakarta; LP3ES.

Wiryono, Herry, dkk. 2004

Pergerakan Pembaharuan Islam, Studi Historis tentang Persatuan Islam (Persis) di Kampung
Serang Provinsi Banten. Bandung: BKSNT.

Iskandar, Mohammad. 2001.

Para Pengemban Amanah. Yogyakarta: Mata Bangsa.

Michrob, Halwany dkk, 1993

Catatan Masa Lalu Banten. Serang: Banten.

Noor, H. Mahpudin. 2006.

Potret Dunia Pesantren. Bandung: Humanidra.

Siraj, Said Aqiel, 1999,

Pesantren Masa Depan. Bandung: Pustaka Hidayah.

Supriatna, Endang. dkk. 2007. Penanaman Nilai Budaya di Pesantren Salafiah. Bandung: BPSNT.

Susilo, Ahmad. 2003.

Strategi Adaptasi Pondok Pesantren. Jakarta: Kucica.

Sukamto. 1991.

Kepemimpinan Kyai dalam Pesantren, Jakarta: LP3ES.

Tim Sejarah, 2000.

Sejarah Pesantren Cipasung Tasikmalaya, Bandung: BPSNT.

Yakub, M.Ed, 1993.

Pondok Pesantren dan Pembangunan Masyarakat Desa, Bandung: Angkasa

\section{Wawancara}

1. K.H Ahyani, 69 th

2. K.H Salim, 65 th

3. Hj. Aisyah. M Sidik, 73 th

4. Jejen, 20 th 